\title{
A study of the effect of povidone-iodine on wound healing
}

\author{
O. J. A. Gilmore \\ M.S., F.R.C.S., F.R.C.S.Ed.
}

\author{
Clare Reid
}

B.Sc., A.I.M.L.S.

\author{
A. Strokon \\ F.R.C.S.Ed.
}

\author{
Surgical Professorial Unit, St Bartholomew's Hospital, London E.C.1 and \\ North Middlesex Hospital, London N.18
}

\begin{abstract}
Summary
The effect of dry powder povidone-iodine (Disadine D.P.) on wound healing was assessed experimentally and clinically. It did not interfere with wound healing macroscopically, histologically or mechanically in Wistar rats. One hundred and one patients undergoing 'clean' elective surgery were included in the controlled clinical study and povidone-iodine did not affect wound healing in any way. In the control group $4 \%$ of patients developed infection compared with none of those sprayed with povidone-iodine. No adverse reaction to povidone-iodine was seen in either study. This antiseptic offers a safe alternative to antibiotics for use at operation whenever there is risk of wound infection from operative bacterial contamination.
\end{abstract}

\section{Introduction}

Interparietal, dry powder povidone-iodine (Disadine D.P.) sprayed into the wound just before closure significantly reduces infection after potentially contaminated abdominal operations (Gilmore and Sanderson, 1975). It reduces wound infection after gridiron appendicectomy and is at least as effective as a polyantibiotic spray containing neomycin, bacitracin and polymixin (Gilmore, Martin and Fletcher, 1973; Gilmore and Martin, 1974). Numerous antiseptics, however, damage the tissues and inhibit healing (Bränemark and Ekholm, 1967). Pollock and Evans (1975) suggested that povidone-iodine acted as a wound irritant and caused secondary sepsis.

An experimental study using rats was therefore carried out to determine the effect of povidoneiodine on wound healing, and a clinical trial determined whether it causes secondary sepsis. Late wound infections often occur after potentially contaminated abdominal procedures (Gilmore and Martin, 1974; Gilmore and Sanderson, 1975) and cannot always be differentiated from secondary sepsis 'that which follows discharge from the wound

Correspondence: Mr O. J. A. Gilmore, St Bartholomew's Hospital, West Smithfield, London EC1A 7BE. of a substance other than pus' (Pollock, 1973).. . For this reason the clinical evaluation was under-i taken in patients undergoing elective, 'clean', $\theta$ non-abdominal operations.

Materials and methods

Experimental study

Seventy-two female, specific pathogen-free, Wistar rats weighing $220-250 \mathrm{~g}$ were used in this study. 3 Under ether anaesthesia following shaving and skin $\bar{\supset}$ disinfection with chlorhexidine gluconate $0.5 \%$ in $70 \%$ methylated spirit, a $4-\mathrm{cm}$, vertical, mid-lipe incision was made through all layers of the anteriorr. abdominal wall. A card was then drawn allocatis the rat to one of two groups. The wounds of the thirty-six rats in group $A$ remained as untreated $\bar{O}$ controls. The open wounds of the thirty-six rats in group B were sprayed with dry powder povidone- $\mathbb{Q}$ iodine (Disadine D.P.) for $5 \mathrm{sec}$, from a distance of $\overrightarrow{\vec{P}}$ approximately $25 \mathrm{~cm}$. All wounds were closed in $\frac{3}{3}$ one layer with seven interrupted $2 / 0$ black silk sutures, each separated by a gap of $0.5 \mathrm{~cm}$.

\section{Assessment of wound healing}

Wound healing was assessed macroscopically, histologically and mechanically in ignorance of the 3 . treatment group.

Macroscopic assessment was made in six rats per group at 3, 5, 7, 14 and 28 days after operation.윽 Wounds were inspected for inflammation, excoriation and wound and stitch abscess formation.

Histological assessment was made in three rats per group at 7 and 28 days after operation. Following 9 killing with ether a rectangle of anterior abdominal ${ }^{N}$ wall measuring $2 \times 1 \mathrm{~cm}$ was excised from each rat in N such a way that there was $1 \mathrm{~cm}$ of tissue either side of the healing incision. Sections were stained witho haematoxylin and eosin and examined under high and low power magnification.

Mechanical assessment was carried out in six rats 0 per group at 3,5, 7, 14 and 28 days after operation. The bursting strength of the abdominal wound was 
measured in the manner described by Prudden, Nishihara and Baker (1957) and de Haan, Ellis and Wilks (1974). The rats were killed with ether; any remaining sutures were then carefully divided but not removed. A pair of Spencer Wells forceps was inserted into the peritoneal cavity through a defect made in the apex of the vagina. A fingercot (Regent Medical Fingercot. L.R.I. Ltd) was then inserted via the same route and connected by a ' $Y$ ' junction to a mercury manometer and a cylinder of carbon dioxide. The pressure was raised at a constant rate of $5 \mathrm{mmHg} / \mathrm{sec}$ until the abdomen burst.

\section{Clinical study}

One hundred and one consecutive patients at the North Middlesex Hospital, London, undergoing elective, 'clean', non-abdominal operations were included in this study. Random allocation of patients to one of two groups was achieved by using a table of random numbers; the code in the form of an 'Advent Calendar' was kept outside the theatre. The surgeon was informed of the spraying procedure to be used just before he started closing the wound. The open wounds of patients in group $\mathbf{S}$ were sprayed with dry powder povidone-iodine and the wounds of the patients in group $\mathrm{T}$ with the propellant alone (dichlorodifluoromethane and trichlorofluoromethane). Spraying was carried out by the runner nurse or theatre technician who, having shaken the aerosol, sprayed the open wound for $10 \mathrm{sec}$ from approximately $25 \mathrm{~cm}$. The deeper layers of all wounds were closed with chromic catgut and the skin with interrupted $2 / 0$ black silk. All closed wounds were sprayed with nobecutane, no other dressing being applied.

A standard form was completed at the end of each operation recording the patient's age, sex, diagnosis and build. Patients with less than $1 \mathrm{~cm}$ of subcutaneous tissue were classified as thin, those with $1-2.5 \mathrm{~cm}$ as average and those with more than $2.5 \mathrm{~cm}$ as obese. The operative procedure, the type of incision, its length, the duration of the operation, the surgeon, and whether the patient was given antibiotics were also recorded.

All wounds were inspected in ignorance of the spraying procedure used by the registrar from the firm which had not performed the operation. A careful watch was kept for evidence of inflammation, excoriation, discharge and local or general reactions. The criteria of Ljungquist (1964) were adopted with regard to infection. The wound was either clean or infected. It was infected if at any time a purulent discharge occurred. If a serous discharge appeared it was swabbed, cultured, and the wound classified according to the resultant culture.

All wounds were inspected at follow-up 6 weeks after operation. Any wound discharging pus after the patient returned home was included in the infected group.

\section{Statistical methods}

The mean bursting pressure of the rat abdomen was calculated for each treatment group on each day of killing. These means were compared using an unpaired Student's $t$-test with standard deviation. The same test was used in the clinical study for comparison of continuous variables, i.e. age, duration of operation and length of incision. The $\chi^{2}$ test was used for two analyses: distribution of patients between the two treatment groups according to build and the number of patients in each group operated on by individual surgeons. Fisher's exact test (Fisher, 1935) was used to analyse data related to the patient's sex and the type of operation.

\section{Results}

\section{Experimental study}

Macroscopic assessment. The wounds were found to be soundly healed in all rats sprayed with povidone-iodine. In the control group two rats had areas of excoriation in the vicinity of the wound, three had wound abscesses and one a stitch abscess. Two rats in the povidone-iodine group had evidence of superficial infection and one had a bead of pus at a stitch site. There was no evidence of reaction to the povidone-iodine in any rat.

Histology. At 1 week there was hyperplasia of the epidermis in all specimens. Granulation tissue was visible between the divided dermis, subcutaneous tissue and panniculus carnosus. Macrophages, foreign body giant cells and some polymorphonuclear cells were visible in both groups around hairs and suture material in the interparietal granulation tissue. These changes were no more marked in one group than the other.

It was equally difficult to see the incision histologically in all rats at 1 month. The sites of the divided rectus muscles were visible and were joined by new muscle and fibrous tissue in similar proportions in both groups. A layer of fibrous tissue was visible in all animals between the healing muscle and the healed peritoneum. Although examination of the sections taken from the incisions at 1 week and 1 month showed some individual variations in appearance, there was no consistent change in one group.

Bursting pressures. The mean bursting pressures of the abdominal wounds of the rats in both groups on the different days are shown as a histogram in Fig. 1. When these are compared there is no statistical significance between the two groups on any day. The mean bursting pressure rose sharply between the third and seventh post-operative days and then levelled out. 
TABLE 1. Distribution of variable factors in both groups

\begin{tabular}{|c|c|c|c|c|}
\hline & & Control & Povidone-iodine & Significance \\
\hline Sex: & $\begin{array}{l}\text { Male } \\
\text { Female }\end{array}$ & $\begin{array}{l}41 \\
12\end{array}$ & $\begin{array}{l}33 \\
15\end{array}$ & $\begin{array}{l}\text { n.s. } \\
\text { n.s. }\end{array}$ \\
\hline \multicolumn{2}{|c|}{ Mean age (years) } & $47 \cdot 4 \pm 19 \cdot 1$ & $51 \cdot 5 \pm 16 \cdot 1$ & n.s. \\
\hline Build: & $\begin{array}{l}\text { Thin } \\
\text { Average } \\
\text { Obese }\end{array}$ & $\begin{array}{r}5 \\
41 \\
7\end{array}$ & $\begin{array}{r}7 \\
30 \\
11\end{array}$ & $\begin{array}{l}\text { n.s. } \\
\text { n.s. } \\
\text { n.s. }\end{array}$ \\
\hline Operation & $\begin{array}{l}\text { Hernia } \\
\text { Breast } \\
\text { Orthopaedic } \\
\text { Scrotal } \\
\text { Miscellaneous } \\
\text { Mean duration (min) }\end{array}$ & $\begin{array}{c}36 \\
5 \\
\\
5 \\
4 \\
\\
3 \\
28 \quad \pm 11 \cdot 7\end{array}$ & $\begin{array}{c}28 \\
5 \\
\\
8 \\
\\
2 \\
5 \\
25 \quad \pm 11 \cdot 7\end{array}$ & $\begin{array}{l}\text { n.s. } \\
\text { n.s. } \\
\text { n.s. } \\
\text { n.s. } \\
\text { n.s. } \\
\text { n.s. }\end{array}$ \\
\hline \multicolumn{2}{|c|}{ Mean length of incision $(\mathrm{cm})$} & $9 \cdot 9 \pm 4 \cdot 0$ & $10 \pm 4 \cdot 3$ & n.s. \\
\hline Surgeon: & $\begin{array}{l}\text { A } \\
\text { B } \\
\text { C } \\
\text { D }\end{array}$ & $\begin{array}{r}20 \\
19 \\
5 \\
9\end{array}$ & $\begin{array}{r}16 \\
16 \\
5 \\
11\end{array}$ & $\begin{array}{l}\text { n.s. } \\
\text { n.s. } \\
\text { n.s. } \\
\text { n.s. }\end{array}$ \\
\hline
\end{tabular}

n.s., Not significant.

\section{Clinical study}

The method of randomization in this study gave an even distribution of patients between both treatment groups, according to all the criteria considered (Table 1). No patient in the study received systemic antibiotics before, during or after operation.

Two patients developed post-operative wound infection (Table 2). Both infected patients were men in the control group, who had undergone herniorrhaphy. One of these patients had a clear serous discharge from the wound at 1 week; the other

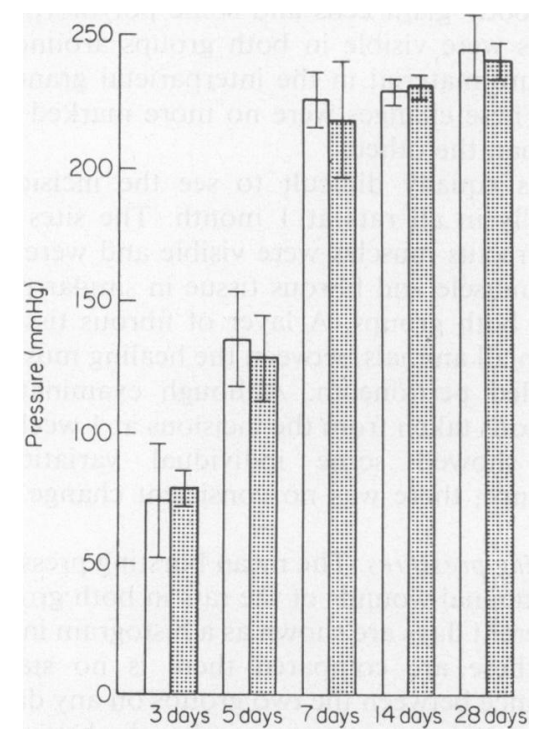

Fig. 1. Mean bursting pressure of rat abdominal wounds (six rats in each group). $\square$, Control; $\approx$, povidoneiodine.

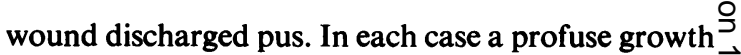
of Staphylococcus aureus was obtained. There was no statistical difference in the incidence of wound $\stackrel{\widetilde{W}}{\widetilde{O}}$ infection between the two treatment groups.

Two patients, one from each group, stated at $\overrightarrow{0}$ follow-up that they had had a clear discharge from $y$ the wound following their leaving hospital. A culture of this fluid was obtained in neither case, so theseo patients have been included in the non-infected group.

Besides these four patients, none developed local $\frac{\varrho}{\circ}$ inflammation, excoriation or a discharge. Through- $\square$ out the study no adverse reaction, local or general, $\overrightarrow{\overrightarrow{0}}$ was seen to either aerosol. These was no clinical 3 evidence that povidone-iodine is an irritant or impairs healing.

TABLE 2. Frequency of wound infection

\begin{tabular}{lcc}
\hline Treatment group & Total & Infected \\
\hline Control & 53 & 2 \\
Povidone-iodine & 48 & 0 \\
& 101 & 2 \\
\hline
\end{tabular}

\section{Discussion}

The results of the experimental study in rats $N$ indicate that dry powder povidone-iodine applied to the open wound with an aerosol does not interfereco with wound healing. There was no difference be- $\mathbb{\Phi}$ tween the treated and control groups when healing $\stackrel{\mathscr{\rho}}{+}$ was assessed macroscopically, histologically and 70 mechanically. There is no evidence that the iodine $\stackrel{+}{\mathbb{P}}$ in povidone-iodine caused either excoriation or 
irritation. The standard 4-cm rat wounds were sprayed for $5 \mathrm{sec}$ and the clinical wounds for $10 \mathrm{sec}$ because the mean length of the latter was $10 \mathrm{~cm}$.

In the clinical study the two post-operative wound infections (both in control patients) were possibly of ward origin, since both occurred 7 days after operation and a growth of Staph. aureus was obtained in each case. No antimicrobial, antibiotic or antiseptic instilled into the wound at operation can be expected to prevent subsequent infections of ward origin.

The fact, however, that $4 \%$ of patients in the control group developed infection compared with none sprayed with povidone-iodine clearly indicates that povidone-iodine does not cause secondary sepsis as suggested by Pollock and Evans (1975).

At the end of an operation every wound contains bacteria. The number of bacteria present varies according to the type of operation and its duration (Davidson, Smith and Smylie, 1971; Gilmore and Sanderson, 1975). In 'clean' cases (when no hollow viscus is incised) of short duration, the inoculum is usually sub-infective. In prolonged 'clean' operations it is possible that the number of bacteria in the wound may reach infective levels. In these cases it would be logical to instil an effective antimicrobial, provided it does not interfere with healing or encourage the emergence of resistant bacterial strains.

Dry powder povidone-iodine is an effective antiseptic in preventing wound infection (Gilmore et al., 1973; Gilmore and Martin, 1974; Gilmore and Sanderson, 1975). It does not induce bacterial resistance (Gilmore and Sanderson, 1975; Houang et al., 1976) and the present studies show that it does not interfere with wound healing. It therefore appears to be a suitable alternative to antibiotics for use at operation whenever there is a risk of wound infection from operative bacterial contamination.

\section{Acknowledgments}

We are most grateful to Mr Richard A. Payne and Mr T. M. Hennebry for allowing their patients to be included in the clinical trial. We thank Mr John A. Lewis and Miss Elaine Laws for statistical advice. We are grateful to the Department of Medical Illustration of St Bartholomew's Hospital for the illustration and Mrs J. C. Constantine for preparing the typescript. We are indebted to Professor G. W. Taylor for his advice and encouragement. Disadine D.P. is a product of Stuart Pharmaceuticals Ltd.

\section{References}

Bränemark, P.I. \& Ekholm, R. (1967) Tissue injury caused by wound disinfectants. Journal of Bone and Joint Surgery, 49, 48.

Davidson, A.I.G., Smith, G. \& Smylie, H.G. (1971) A bacteriological study of the immediate environment of a surgical wound. British Journal of Surgery, 58, 326.

De HaAN, B.B., Ellis, H. \& Wilks, M. (1974) Role of infection on wound healing. Surgery, Gynecology and Obstetrics, 138, 693.

Fisher, R.A. (1935) The logic of induced inference. Journal of Royal Statistical Society, 98, 39.

Gilmore, O.J.A. \& MARTIN, T.D.M. (1974) The aetiology and prevention of wound infection in appendicectomy. British Journal of Surgery, 61, 281.

Gilmore, O.J.A., Martin, T.D.M. \& Fletcher, B.N. (1973) Prevention of wound infection after appendicectomy. Lancet, i, 220.

Gilmore, O.J.A. \& Sanderson, P.J. (1975) Prophylactic interparietal povidone iodine in abdominal surgery. British Journal of Surgery, 62, 792.

Houang, E., Gilmore, O.J.A., Reid, C. \& Shaw, E. (1976) Absence of bacterial resistance to povidone iodine. Journal of Clinical Pathology, 29, 752.

LJUNGQUIST, V. (1964) Wound sepsis after clean operations. Lancet, i, 1095.

Pollock, A.V. (1973) Wound infection in acute appendicitis. Lancet, ii, 1384.

Pollock, A.V. \& Evans, M. (1975) Povidone iodine for the control of surgical wound infection: a controlled clinical trial against topical cephaloridine. British Journal of Surgery, 62, 292.

Prudden, J.F., Nishihara, G. \& Baker, L. (1957) The acceleration of wound healing with cartilage. Surgery, Gynecology and Obstetrics, 105, 283. 